Tropical Journal of Pharmaceutical Research October 2017; 16 (10): 2501-2506

ISSN: $1596-5996$ (print); 1596-9827 (electronic)

(C) Pharmacotherapy Group, Faculty of Pharmacy, University of Benin, Benin City, 300001 Nigeria.

All rights reserved.

Available online at http://www.tjpr.org

Original Research Article

http://dx.doi.org/10.4314/tjpr.v16i10.25

\title{
Development of a high performance liquid chromatography method for simultaneous analysis of theophylline, guaifenesin and diphenhydramine in an elixir
}

\author{
Hayun*, Yahdiana Harahap and Maria O Puspasari \\ Faculty of Pharmacy, Universitas Indonesia, Depok, 16424, West Java, Indonesia \\ *For correspondence: Email: hayun.ms06@gmail.com; Tel: +62217270031; Fax: +62217863433 \\ Sent for review: 17 May 2017 \\ Revised accepted: 12 September 2017
}

\begin{abstract}
Purpose: To develop and validate a new low-cost high performance liquid chromatography (HPLC) method for simultaneous analysis of theophylline (TH), guaifenesin (GF) and diphenhydramine hydrochloride $(\mathrm{DH})$ in elixir dosage form.

Methods: Chromatographic conditions were an isocratic elution with C18-Kromasil@ column (250 x 4.6 $\mathrm{mm}, 5 \mu \mathrm{m})$, methanol-water $(1: 1, \mathrm{v} / \mathrm{v}, \mathrm{pH} 3,0)$ as mobile phase, flow rate $1.0 \mathrm{~m} / \mathrm{min}$ and $\mathrm{UV}$ detector at $\lambda 218 \mathrm{~nm}$. The method was validated for selectivity, linearity, LOD-LOQ, precision, and accuracy.

Results: Retention time of TH, GF and DH was 3.3, 5.3 and 9.1 min, respectively. The method showed good selectivity, calibration curves were linear over the concentration range of $1.000-10.002 \mu \mathrm{g} / \mathrm{mL}$, $0.801-8.008 \mu \mathrm{g} / \mathrm{mL}$, and $0.251-2.514 \mu \mathrm{g} / \mathrm{mL}\left(r^{2}>0.999\right)$. LOD was $0.1093,0.16520$, and 0.0706 $\mu \mathrm{g} / \mathrm{mL}$, while $L O Q$ was $0.3645,0.5506$, and $0.2354 \mu \mathrm{g} / \mathrm{mL}$ for $\mathrm{TH}$, GF and $\mathrm{DH}$, respectively. Recovery accuracy was 99.77 - 101.10, 100.50 - 101.95 and 99.20 - 100.13 \% for TH, GF and DH, respectively; precision (RSD) was $<2.0$.

Conclusion: The proposed method is highly selective, sensitive, precise, and accurate, and would suitable for the simultaneous analysis of TH, GF, and DH in elixir dosage form. Since methanol is cheaper than acetonitrile, the application of the method may reduce the cost of analysis.
\end{abstract}

Keywords: Simultaneous analysis, Theophylline, Guaifenesin, Diphenhydramine hydrochloride, Elixir

Tropical Journal of Pharmaceutical Research is indexed by Science Citation Index (SciSearch), Scopus, International Pharmaceutical Abstract, Chemical Abstracts, Embase, Index Copernicus, EBSCO, African Index Medicus, JournalSeek, Journal Citation Reports/Science Edition, Directory of Open Access Journals (DOAJ), African Journal Online, Bioline International, Open-J-Gate and Pharmacy Abstracts

\section{INTRODUCTION}

Theophylline (TH), guaifenesin (GF) and diphenhydramine hydrochloride (DH) (Figure 1) is a combination of the active ingredients contained in elixir dosage form. This combination is used for a treatment of bronchial asthma and asthmatic bronchitis conditions $[1,2]$. The reversed phase high performance liquid chromatographic (HPLC) method has been widely used for the assay of one or two active ingredients simultaneously in dosages form containing TH, GF and or $\mathrm{DH}$, or other active ingredients [3-8]. The HPLC methods have also been used for the simultaneous analysis of these three active ingredients in a mixture with some other active substances or excipients using acetonitrile-phosphate buffer pH 3.2 as mobile phase $[9,10]$.

Acetonitrile is an excellent solvent for mobile phase of reversed phase HPLC. However, it is relatively expensive solvent and sometimes difficult to obtain. Therefore it is necessary to develop an alternative HPLC method using another solvent as mobile phase. Methanol is the most suitable solvent replacement for acetonitrile. The solvent is cheaper, easier to 
obtain and more polar than acetonitrile, reducing the risk of solid buffer precipitation. However, methanol has a weaker elution strength and a higher back pressure $[11,12]$. The objective of the present study was the development and validation of a new reversed-phase HPLC method for simultaneous analysis of $\mathrm{TH}, \mathrm{GF}$ and $\mathrm{DH}$ in elixir dosage form, using a mixture of methanol-water as mobile phase.

\section{EXPERIMENTAL}

\section{Materials and reagents}

Reference standard of $\mathrm{TH}, \mathrm{GF}$ and $\mathrm{DH}$ were obtained from the National Agency of Drug and Food Control (NA-DFC) of Republic of Indonesia. Methanol used was HPLC grade (Merck), phosphoric acid was of analytical grade (Merck), and double distilled water (Otsuka) and elixir sample containing TH, GF and DH (Tusapress ${ }^{\circledR}$ ) were purchased from commercial source.

\section{Preparation of standard and sample solution}

A stock solution of analytes was prepared by dissolving $50.0 \mathrm{mg} \mathrm{TH}, 40.0 \mathrm{mg} \mathrm{GF}$, and $12.5 \mathrm{mg}$ $\mathrm{DH}$ accurately weighed, in double distilled water up to $100.0 \mathrm{~mL}$, series of dilution were performed with selected mobile phase to give working standard for individual and mixture of analytes with the concentrations of 5.0, 4.0 and 1.25 $\mu \mathrm{g} / \mathrm{mL}$, respectively. A sample solution was prepared by dissolving a certain amount of weight equivalent to approximately $5.0 \mathrm{~mL}$ of the sample in mobile phase to give $100.0 \mathrm{~mL}$ of solution, then performed filtration and a series of dilution to give sample solution with the concentration of $5.0,4.0$ and $1.25 \mu \mathrm{g} / \mathrm{mL}$ calculated of the labeled amount of $\mathrm{TH}, \mathrm{GF}$, and $\mathrm{DH}$, respectively.

\section{HPLC conditions}

High performance liquid chromatography (HPLC) equipped with $\mathrm{Kromasil}^{\circledR}-\mathrm{C} 18$ column $(250 \times 4.6$ $\mathrm{mm}, 5 \mathrm{~m}$ ), pump (Shimadzu LC-10AD), UV-Vis detector (Shimadzu SPD-10A), and syringe 20.0 $\mu \mathrm{L}$ (Hamilton Co. Nevada) were used in this study. The detector was set at $218 \mathrm{~nm}$. The mobile phase of the various composition was prepared as mixture of water and methanol (4:1, $3: 2$ and $1: 1 \mathrm{v} / \mathrm{v})$, then adjusted by addition of phosphoric acid to a $\mathrm{pH}$ of 3.0 , filtered using 0.45 $\mu \mathrm{m}$ membrane filter and degassed by sonication for $15 \mathrm{~min}$. The flow rate was $1.0 \mathrm{ml} / \mathrm{min}$ isocratically. The retention time (tR), and capacity factor ( $\left.k^{\prime}\right)$, HETP, the number of theoretical plates $(\mathrm{N})$, tailing factor $(\mathrm{Tf})$, and separation (R) of the chromatogram peaks resulting from the injections of the mixture of three active ingredients solution into the HPLC were calculated. One of the compositions of the mobile phase which provided the best characteristics for separation was selected. The replicate injections into HPLC with selected condition were also performed to evaluate the precision of the instrument.

\section{Method validation}

The analytical method validation was performed following International Conference on Harmonization (ICH) Q2 guidelines (2005) [13], covering the selectivity, linearity, limit of detection (LOD), limit of quantitation (LOQ), precision and accuracy. The selectivity was evaluated by injecting the blank sample solution, the sample solution, and the standard solutions into the chromatograph. The presence of interferences on the chromatogram peaks of analytes were observed [13].

The linearity of the proposed methods was evaluated by determining the correlation coefficient $\left(r^{2}\right)$ value of linear regression analysis $(Y=a+b X)$ of calibration curves of the analytes [13], in the concentrations range of $1.0-10.0$ $\mu \mathrm{g} / \mathrm{mL}$ for $\mathrm{TH}, 0.8-8.0 \mu \mathrm{g} / \mathrm{mL}$ for $\mathrm{GF}$, and 0.25 $2.5 \mu \mathrm{g} / \mathrm{mL}$ for $\mathrm{DH}$, respectively.

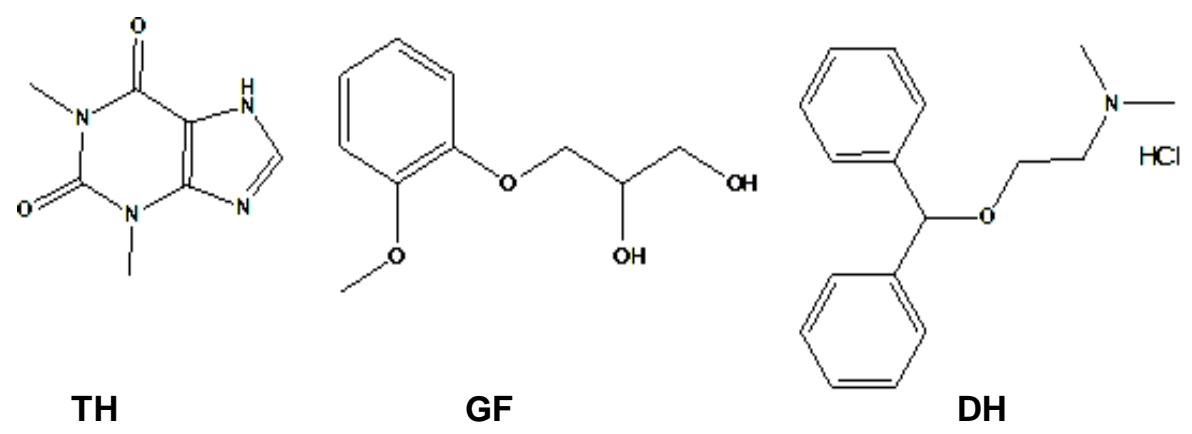

Figure 1: Chemical structures of theophylline (TH), guaifenesin (GF), and diphenhydramine hydrochloride (DH) 
The $L O D$ and the $L O Q$ were determined using data of standard deviation of the response $(\sigma)$ and the slope of the calibration curve (S). $\angle O D=$ $3.3 \mathrm{\sigma} / \mathrm{S}$ and $L O Q=10 \mathrm{\sigma} / \mathrm{S}$, respectively.

Precision was evaluated by performing repeatability and intermediate precision test. Repeatability (intra-day) was assessed by analyzing the analytes in the sample solutions at $100 \%$ levels calculated from the concentration of the analytes in the label of the sample in 6 replicate. Intermediate precision was assessed by determining the analytes in the sample on three consecutive days in triplicate, respectively. The values of relative standard deviation (RSD) for the repeatability and the intermediate precision were reported [13].

The accuracy was tested by determining recovery values of the analytes in the sample addition [13]. Accurately weighed standard $\mathrm{TH}$, GF and DH were spiked to the sample, diluted with mobile phase solvent to give three different concentration levels $(80,100$, and $120 \%$ of the labeled amounts of each analyte in the sample), and analyzed by the proposed methods in triplicate.

\section{RESULTS}

Initial method development was the selection of mobile phase compositions. UV detector was set at $\lambda 218 \mathrm{~nm}$. The wavelength is maximum $\lambda$ of diphenhydramine $\mathrm{HCl}$, which is the component with the smallest concentration and absorption. In the $\lambda$, the three analytes are best detected. The mixture of methanol and water $(1: 1, \mathrm{v} / \mathrm{v}, \mathrm{pH}$ 3.0) which provided the best chromatographic characteristics was selected as a mobile phase. Under this condition, retention time (tR) of $\mathrm{TH}$, GF and DH were 3.3, 5.2, and $9.1 \mathrm{~min}$, respectively (Figure 2). Five replicate injection consecutively of working standard solution gave RSD not more than $2.0 \%$ for all analytes. The data indicates a good precision of the chromatographic systems.

The method showed a good selectivity. There was no observed interference from the sample components and others at Rf of TH, GF and DH. The calibration curves between the concentration of TH, GF and DH and their peaks area showed good linear relationship over the concentration range of $1.000-10.002 \mu \mathrm{g} / \mathrm{mL}, 0.801-8.008$ $\mu \mathrm{g} / \mathrm{mL}$, and $0.251-2.514 \mu \mathrm{g} / \mathrm{mL}$, for TH, GF and $\mathrm{DH}$, respectively $\left(r^{2}=0.999\right)$. The LOD values obtained were $0.1093,0.16520$, and 0.0706 $\mu \mathrm{g} / \mathrm{mL}$, while the LOQ were $0.3645,0.5506$, and $0.2354 \mu \mathrm{g} / \mathrm{mL}$ for $\mathrm{TH}$, GF and $\mathrm{DH}$, respectively (Table 1).

The precision and accuracy of the method were satisfactory. The RSD values of repeatability and intermediate precision obtained were all less than $2.0 \%$ (Table 2), and the mean of recovery values obtained were $99.77-101.10 \%, 100.50$ $101.95 \%$ and $99.20-100.13 \%$ for TH, GF and $\mathrm{DH}$, respectively (Table 3 ).

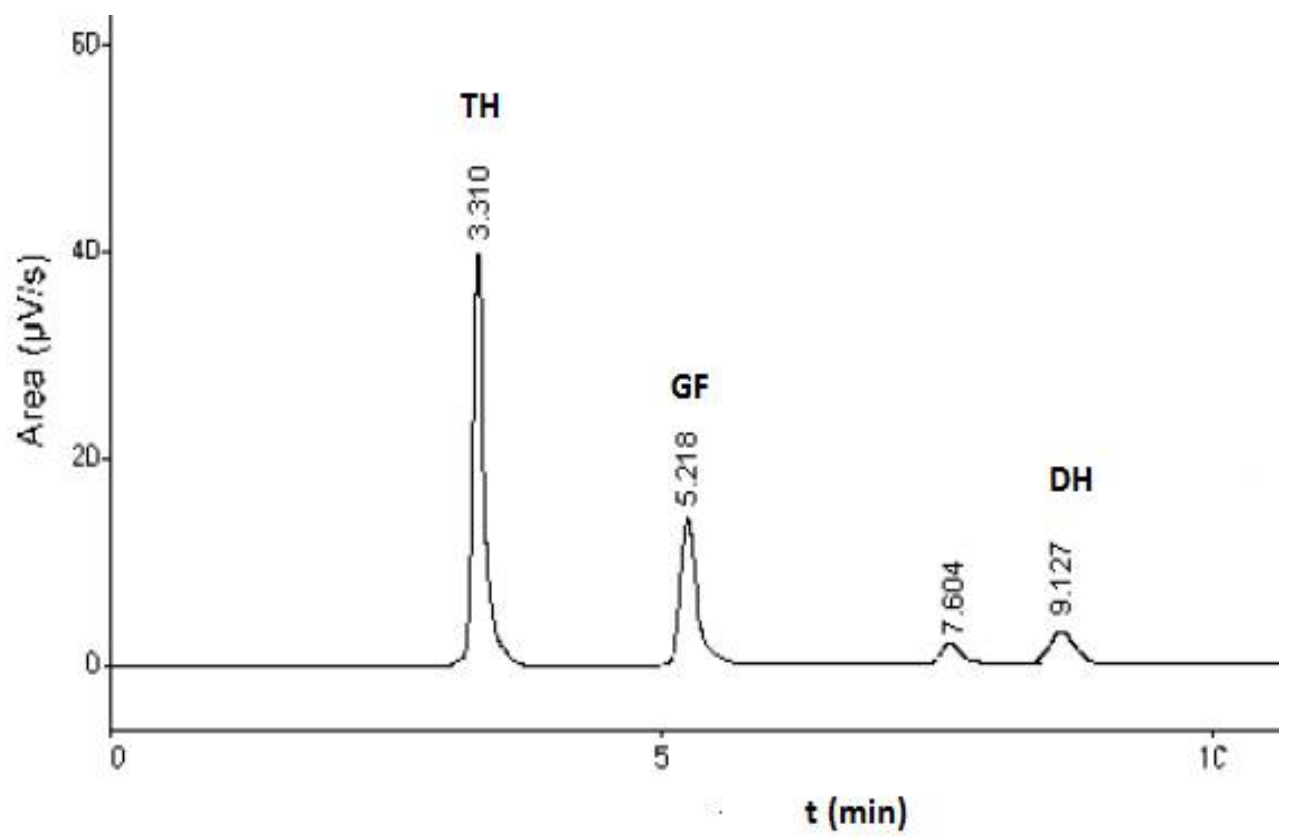

Figure 2: HPLC chromatogram of $20 \mu \mathrm{L}$ injection of sample elixir solution containing theophylline (TH), guaifenesin (GF) and diphenhydramine hydrochloride (DH). 
Table 1: Characteristics of the calibration curves, the limit of detection (LOD) and the limit of quantitation (LOQ) of HPLC method for the simultaneous analysis of theophylline (TH), guaifenesin (GF) and diphenhydramine hydrochloride $(\mathrm{DH})$

\begin{tabular}{lccc}
\hline Parameter & TH & GF & DH \\
\hline Range $(\mu \mathrm{g} / \mathrm{mL})$ & $1.000-10.002$ & $0.801-8.008$ & $0.251-2.514$ \\
Regression Eq. $(\mathrm{Y})^{~}{ }^{\prime}{ }^{\prime}:$ & 314.15 & -650.75 & -1385.30 \\
Intercept $(\mathrm{a})$ & 53385 & 32871 & 36765 \\
Slope $(\mathrm{S})=(\mathrm{b})$ & 1946.001 & 1811.783 & 865.470 \\
Standard dev of intercept $(\sigma)$ & 0.1203 & 0.1819 & 0.0776 \\
LOD $(\mu \mathrm{g} / \mathrm{mL})$ & 0.3645 & 0.5511 & 0.2354 \\
LOQ $(\mu \mathrm{g} / \mathrm{mL})$ & 0.999 & 0.999 & 0.999 \\
Correlation coefficient $(\mathrm{r})$ & &
\end{tabular}

Table 2: Precision of the method

\begin{tabular}{|c|c|c|c|c|c|c|}
\hline \multirow{2}{*}{ Analyte } & \multirow{2}{*}{$\begin{array}{l}\text { Level } \\
(\%)\end{array}$} & \multirow{2}{*}{$\begin{array}{l}\text { Conc }^{1)} \\
\left(\mu \mathrm{g} / \mathrm{mL}^{1}\right)\end{array}$} & \multicolumn{2}{|c|}{$\begin{array}{l}\text { Repeatabilty } \\
(n=6)^{2)}\end{array}$} & \multicolumn{2}{|c|}{$\begin{array}{l}\text { Intermediate precision } \\
(\mathrm{n}=9)^{2)}\end{array}$} \\
\hline & & & $\begin{array}{c}\text { Mean conc } \\
(\mu g / m L)\end{array}$ & $\begin{array}{l}R S D \\
(\%)\end{array}$ & $\begin{array}{c}\text { Mean conc } \\
(\mu g / m L)\end{array}$ & $\begin{array}{l}R S D \\
(\%)\end{array}$ \\
\hline $\mathrm{TH}$ & 100 & 5.283 & 5.324 & 0.55 & 5.303 & 0.93 \\
\hline GF & 100 & 4.226 & 4.262 & 0.29 & 4.248 & 0.55 \\
\hline $\mathrm{DH}$ & 100 & 1.321 & 1.325 & 0.76 & 1.317 & 1.05 \\
\hline
\end{tabular}

"Calculated from weight of the sample used, concentration of the analytes in the label and dilution; ${ }^{2} \mathrm{n}=$ number of repetitive determinations.

Table 3: Accuracy of the method

\begin{tabular}{|c|c|c|c|c|c|c|}
\hline \multirow{2}{*}{ Analyte } & \multirow{2}{*}{$\begin{array}{l}\text { Level } \\
\text { (\%) }\end{array}$} & \multicolumn{2}{|r|}{$\begin{array}{l}\text { Analyte conc } \\
(\mu \mathrm{g} / \mathrm{mL})\end{array}$} & $\begin{array}{c}\text { Results of analysis } \\
(n=3)\end{array}$ & \multirow{2}{*}{$\begin{array}{c}\text { Mean } \\
\text { spiked recovery } \\
(\mu \mathrm{g} / \mathrm{mL}) \\
(\mathrm{e}-\mathrm{d})\end{array}$} & \multirow{2}{*}{$\begin{array}{l}\text { Percent } \\
(\%) \\
\text { recovery } \\
{[(f / c) \times 100]}\end{array}$} \\
\hline & & Spiked & Sample & $\begin{array}{c}\text { Mean total conc } \\
(\mu \mathrm{g} / \mathrm{mL})\end{array}$ & & \\
\hline$a$ & $\mathrm{~b}$ & $C$ & $d$ & $\mathrm{e}$ & $f$ & $g$ \\
\hline \multirow[t]{3}{*}{$\mathrm{TH}$} & 80 & 2.005 & 2.008 & 4.035 & 2.027 & 101.10 \\
\hline & 100 & 2.503 & 2.510 & 5.012 & 2.502 & 99.96 \\
\hline & 120 & 3.008 & 3.012 & 6.013 & 3.001 & 99.77 \\
\hline \multirow[t]{3}{*}{$\overline{G F}$} & 80 & 1.601 & 1.608 & 3.223 & 1.615 & 100.87 \\
\hline & 100 & 2.001 & 2.010 & 4.050 & 2.040 & 101.95 \\
\hline & 120 & 2.401 & 2.412 & 4.825 & 2.413 & 100.50 \\
\hline \multirow[t]{3}{*}{$\mathrm{DH}$} & 80 & 0.502 & 0.499 & 0.997 & 0.498 & 99.20 \\
\hline & 100 & 0.626 & 0.623 & 1.245 & 0.622 & 99.36 \\
\hline & 120 & 0.751 & 0.748 & 1.500 & 0.752 & 100.13 \\
\hline
\end{tabular}

"Calculated from weight of the sample used, the concentration of the analytes resulted from repeatability study and dilution

\section{DISCUSSION}

Theophylline (TH), guaifenesin (GF) and diphenhydramine hydrochloride $(\mathrm{DH})$ are a combination of the active ingredients in elixir dosage form for oral administration [1]. The UV absorption spectra of $\mathrm{TH}$, GF and DH display considerable overlap. Moreover, oral solution generally contains flavouring, sweetening or coloring agent [3]. Several papers have reported the use of reverse phase HPLC methods for simultaneous analysis of these three active ingredients in a mixture with some other active substances or excipients $[9,10]$. However, due to cost or solvent availability, it is necessary to develop an alternative method using another solvent as a mobile phase.
The price of methanol is about $1 / 4$ times that of acetonitrile [14]. In addition, methanol is easier to obtain and more polar than acetonitrile, reducing the risk of solid buffer precipitation [11]. Hence the proposed method would be less costly to perform routine determination of TH, GF and DH in elixir dosage form in the pharmaceutical industry.

The results of the method validation showed that all parameters are within acceptable limits. The presence of excipients in the formulations did not cause any interference with $\mathrm{TH}, \mathrm{GF}$, and $\mathrm{DH}$ peaks. Thus the method is selective for simultaneous determination of $\mathrm{TH}, \mathrm{GF}$, and $\mathrm{DH}$. Good linearity was observed with either 
concentration range exceeds the concentrations range employed in the test substance with a regression coefficient $\left(r^{2}\right)=0.999$, and the LODLOQ obtained indicating a high degree of sensitivity.

The RSD of intra-day measurements of TH, GF and $\mathrm{DH}$ were $0.55,0.29$ and $0.76 \%$, respectively, while the RSD of intermediate precision of $\mathrm{TH}, \mathrm{GF}$ and $\mathrm{DH}$ were $0.93,0.55$ and $1.05 \%$. The RSD values obtained were less than RSD max, thus the method is precise. The recovery values obtained were $99.77-101.10 \%$, $100.50-101.95 \%$ and $99.20-100.13 \%$ for $\mathrm{TH}$, GF and DH, respectively. Thus the method is accurate. Overall, the data indicate that the method is suitable as an alternative for the determination of $\mathrm{TH}, \mathrm{GF}$ and $\mathrm{DH}$ in elixir dosage form simultaneously.

The proposed method consumed about $5 \mathrm{ml}$ of methanol to run once analysis, while the previous method using acetonitrile-phosphate buffer [9] consumed about $3 \mathrm{ml}$ of acetonitrile. Taking into account that methanol is cheaper than acetonitrile, this result could be an inspiration for the development of lower-cost HPLC methods for the determination of $\mathrm{TH}$ and/or GF in other dosage forms for asthma medications.

\section{CONCLUSION}

An HPLC method for the simultaneous analysis of $\mathrm{TH}, \mathrm{GF}$ and $\mathrm{DH}$ has been developed and validated. The method is selective, sensitive, precise and accurate, so is a suitable alternative for the simultaneous analysis of $\mathrm{TH}, \mathrm{GF}$ and $\mathrm{DH}$ in elixir dosage form. Methanol is cheaper than acetonitrile, hence the use of methanol may reduce the cost of the analysis.

\section{DECLARATIONS}

\section{Acknowledgement}

The authors are thankful to Faculty of Pharmacy, Universitas Indonesia, Depok, West Java, Indonesia, for providing research facilities for this study.

\section{Conflict of Interest}

No conflict of interest associated with this work.

\section{Contribution of Authors}

The authors declare that this work was done by the authors named in this article and all liabilities pertaining to claims relating to the content of this article will be borne by them.

\section{Open Access}

This is an Open Access article that uses a funding model which does not charge readers or their institutions for access and distributed under the terms of the Creative Commons Attribution License (http://creativecommons.org/licenses/by/ 4.0) and the Budapest Open Access Initiative (http://www.budapestopenaccessinitiative.org/rea d), which permit unrestricted use, distribution, and reproduction in any medium, provided the original work is properly credited.

\section{REFERENCES}

1. Ikatan Apoteker Indonesia. Informasi Spesialite Obat Indonesia, 2012, Vol 47, PT ISFI Penerbitan, Jakarta, Indonesia

2. Ritter JM, Lewis LD, Mant TG, Ferro L. A Textbook of Clinical Pharmacology and Therapeutics, 2008, 5th ed. Hodder Arnold, 338 Euston Road, London; pp 234-244.

3. United States Pharmacopeial and National Formulary. United States Pharmacopoeia 30-NF 25 (CD-ROM). United States Pharmacopeial Convention, Inc, 2007, Rockville, p 3326.

4. Ansari M, Kazemipour M, Shahriar M. Simultaneous Quantitation of Theophylline and Guaifenesin in Syrup by HPLC, Derivative and Derivative Ratio Spectrophotometry for Quality Control Purposes. Iranian J Pharmacol Ther 2006; 5(1): 67-72.

5. Panda SS, Kumar BVVR, Mohanta G. Stability-indicating RP-HPLC method for simultaneous estimation of levosalbutamol sulfate and theophylline in combined dosage form. Braz J Pharm Sci 2013; 49(3): 475-490

6. Mohamed A, Korany MA, Fahmy OT, Mahgoub H, Maher HM. High performance liquid chromatographic determination of some guaiphenesin-containing coughcold preparations. J Adv Res 2011; 2: 121-130

7. Ahmed NR, Lottfi SN. High performance liquid chromatographic method for the determination of guaifenesin in pharmaceutical syrups and in environmental samples. J Baghdad for Sci 2013; 10(3): 1014-1021.

8. Kanakal MM, Majid ASA, Sattar MZA, Ajmi NS, Majid AMSA. Buffer-Free High Performance Liquid Chromatography Method for the Determination of Theophylline in Pharmaceutical Dosage Forms. Trop J Pharm Res 2014; 13(1): 149-153

9. El-Gindy A, Emaraa S, Mostafa A. Application and validation of chemometrics-assisted spectrophotometry and liquid chromatography for the simultaneous determination of six-component pharmaceuticals. $J$ Pharm Biomed Anal 2006; 41: 421-430

10. Mallu UR, Bobbarala V, Penumajji S. Analysis Of Cough and Analgesic Range of Pharmaceutical Active 
Hayun et al

Ingredients Using RP-HPLC Method. Int J Pharm Bio Sci 2011; 2(3): 439-452.

11. GL Science Inc. Switching the mobile phase from Acetonitrile to Methanol, 2015. Available from: http://www.lifescience.ca/DATA/CATALOGUE/141 v A cetonitrile_versus_Methanol_Technical_Note.pdf.

12. Shimadzu. Differences Between Using Acetonitrile and Methanol for Reverse Phase Chromatography, 2015.
Available from: http://www.shimadzu.com/an/hplc/ support/lib/ Ictalk/35/35lab.html.

13. ICH Harmonized Tripartite Guidelines. Validation of Analytical Procedures: Text and Methodology, Q2 (R1), Geneva, Nov 2005. Available from: http://www.gmpcompliance.org/guidemgr/files/Q2(R1).PDF

14. Merck Chemicals [cited 31 Oct 2016]. Available from: https://wahanahilabtech.wordpress.com/category/merckchemicall 